\title{
ISSUES OF TROPICAL FOREST TRANSFORMATION IN ASHANTI REGION, GHANA: TESTING TRADITIONAL PERCEPTION AND ASSUMPTION
}

\author{
K. O. Agyeman \\ ${ }^{2}$ Department of Planning, College of Architecture, KNUST, Kumasi. \\ Email: kwasi.1955@yahoo.co.uk \\ Koagyeman.cap@knust.edu.gh
}

\begin{abstract}
:
Studies have revealed that there was a dramatic loss of forests in West Africa during the 20th century due to pressure of population growth and poverty. However some scholars have challenged this view. This paper adopts a political ecology approach to argue that the dominant global discourse of tropical deforestation obscures the more complex process that contributes to changes in forest cover and landscapes. The paper examines how livelihood strategies, trade, and ecology have interacted to alter production cycles, tenure systems and the extent and composition of forest cover during the pre-colonial, colonial and post-colonial periods. Consequently, a focus on forest cover change as opposed to deforestation could provide a better understanding of the relationship between forest and forest farming systems. Subsequently, the paper suggests more effective ways of engaging in sustainable tropical forest management in the Ashanti Region of Ghana.
\end{abstract}

Keywords: Tropics, Deforestation, Transformation, Ashanti, Traditional, Perception

\section{INTRODUCTION}

West Africa is said to have experienced the highest rates of tropical deforestation in Africa, paralleling the trends in the Amazon basin in South America (FAO 1993, 1997; Myers, 1991; WRI, 1990). Some researchers of West African forest claim that less than one-fifth of the precolonial forest area remains at present, and this too is vanishing at a rapid rate due to pressures of population growth and poverty (Myers, 1994; Sayer et al., 1992; Brown and Pearce, 1994).

Such global assessments of deforestation rates and their causes have heavily influenced how governments in West Africa conceptualise and implement policies of rural and regional development. In Ghana, the arguments and figures provided by the international agencies are repeatedly invoked as the basis for introducing policies that aim at arresting deforestation (Dickson, 1983; Benneh, 1985; Nsiah- Gyabaah, 1996). Many studies often cite the Food and Agriculture Organization (FAO) or World Resources Institute (WRI) statistics which assert that 8.6 million hectares of the "closed forest zone' that existed around the turn of the $20^{\text {th }}$ century in Ghana, has been lost to logging and 
farm encroachment (Hawthorn and Musah, 1995; Gyasi et al., 1995; Nsiah-Gyabaah, 1996; Benhin and Barbier, 2004; Kuofor, 2004).

Recent path-breaking research by scholars such as Fairhead and Leach (1996, 1998) and Amanor (1994 and 2002) have fundamentally challenged this perspective towards deforestation in West Africa. They argued that the estimates were based on questionable definitions, assumptions, and methods of calculations that misrepresent the history of West African forests and the relationship between those forests and the people. They claim that most of the estimates of deforestation rates assumed that the closed forest zone represented 'pristine', 'original', or 'virgin' tropical forests, and used this assumption to reinforce Malthusian arguments linking population growth and poverty with deforestation (Leach and Fairhead, 2000). By conducting a historical analysis of forested areas in several countries in West Africa, these scholars have shown that much of the closed forest zone was rarely ever 'virgin' or 'untouched' as assumed. Their studies of Guinea and other countries in the region show that the patterns and processes of forest cover change prior to the $20^{\text {th }}$ century have been remarkably complex, expanding during certain periods and declining in others through the actions of rural communities.

The challenge to 'reframe' deforestation is not merely directed towards scientific researchers engaged in assessing vegetational change, but also towards policy makers and international experts who advocate various kinds of interventions in forestry, agriculture, and natural resource management. The conventional views held in these circles regarding the one-way impact of population growth and landuse on forests do not take into account the different ways in which people have actually worked with the ecological processes. As new research on forest and landscape change points out, a historically informed perspective can reveal the important ways in which inhabitants have not only converted forests to other landuses, but also done the reverse and enriched soils and vegetational diversity, and increased tree cover in these regions (see Amanor, 1994; Fairhead and Leach, 1996, 1998; Batterbury and Bebbington, 1999). More importantly, a reappraisal of the history of forest cover change, as opposed to forest loss, can allow us to understand the varied social, economic, and ecological processes that have shaped the livelihood strategies of rural households, and enabled new ways of thinking about and approaching agroforestry and natural resource management in the moist deciduous forest zones of West Africa.

This paper seeks to explore ways in which ideas about the 'tropics', 'primitive civilization', and equilibrium ecology have intersected to inform the mainstream discourse on tropical deforestation in Ghana. The paper attempts to show how these ideas contribute to problematic assumptions underlying official and scientific assessments of deforestation in Ghana. An alternative analytical framework for understanding how forest cover changed overtime using the Ashanti Region of Ghana is presented.

\section{RESEARCH METHODOLOGY}

This paper is based on a research in the Ashanti Region from 2003 to 2007. Secondary data on land and forest resources were obtained from government economic review publications and reports on regional and district studies. Purposive sampling was adopted in the selection of sixteen fringe communities and households for the primary data collection. A total of 60 rural households in the six (6) sub-regions volunteered to be interviewed for the research (see Table 1). Interviews were conducted with 44 males (73.3 percent) and 16 females (26.7 percent). Household interviews were conducted to assemble their perceptions about land conversion and forest cover change in the region. Also, key informant interviews and focus groups discussions (FGDs) were conducted.

Institutional surveys using structured questionnaires were conducted in the decentralized departments including Agricultural Extension 
Services, Crop Services, the Forest Service Division, the Environmental Protection Agency the Ministry of Local Government and Rural Development. Structured questionnaires were used for the household surveys. Fig. 1 shows the sampled fringe communities for the surveys (Agyeman, 2008).

\section{RESULTS AND DISCUSSION}

Framework for Analysing Land Conversion and Forest Cover Change in Ghana

The first step in finding an approach that avoids would be more appropriate to use the term 'forest cover change' for a better understanding of the ways in which landscapes have been reshaped and transformed. This change in terminology would refocus attention on how different biophysical and social processes mutually shape the extent, species, composition, and vegetational quality of forested areas over time. It would enable us to recognize that the process of forest cover change can take many directions. For instance, forest clearings in some areas may be accompanied by afforestation of

Table 1: Distribution of Respondents in the Sub-Regions of Ashanti

\begin{tabular}{llll}
\hline \multicolumn{1}{c}{ Sub-Region } & Number of Respondents & Land Uses \\
\hline Bekwai (Amansie) & 8 & 4 & Cocoa \\
& & 1 & Oil Palm \\
Manso Nkwanta & 9 & 3 & Food Crop (Mixed) \\
& & 6 & Cocoa \\
Obuasi & 10 & 3 & Food Crop (Mixed) \\
& & 5 & Cocoa \\
Juaben & 9 & 5 & Oil Palm \\
& & 6 & Oil Palm \\
Offinso & 8 & 3 & Food Crop (Mixed) \\
& & 5 & Tomato (Monocrop) \\
Mampong & \multirow{2}{*}{16} & 2 & Oil Palm \\
& & 1 & Food Crop (Mixed) \\
& & 5 & Maize (Monocrop) \\
Total & \multirow{2}{*}{$\mathbf{6 0}$} & 5 & Yam (Monocrop) \\
& & 1 & Cassava (Monocrop) \\
\hline
\end{tabular}

Source: Author's Construct, 2008

the stereotypes of tropical deforestation is to recongnise the limitations of the term itself. Hamilton and Pearce (1988) in Forysth (2003) noted that the generic term "deforestation" is used so ambiguously that it is virtually meaningless as a description of land-use change.

Rather than using the term 'deforestation' with its accompanying imagery of unidirectional change from a 'pristine' forested state to a complete loss of forest caused by human action, it other areas that were not previously forested which may result in new combinations of naturally-growing and cultivated tree and food crops, and different patterns of vegetational quality. The focus on forest cover change allows us to recognize the historical experiences of people who live within and work these landscapes (Diaw, 1998). It enables us to view forest and landscape change as a dynamic process that reveals the "biogeographical outcomes of social relations in the context of particular spa- 


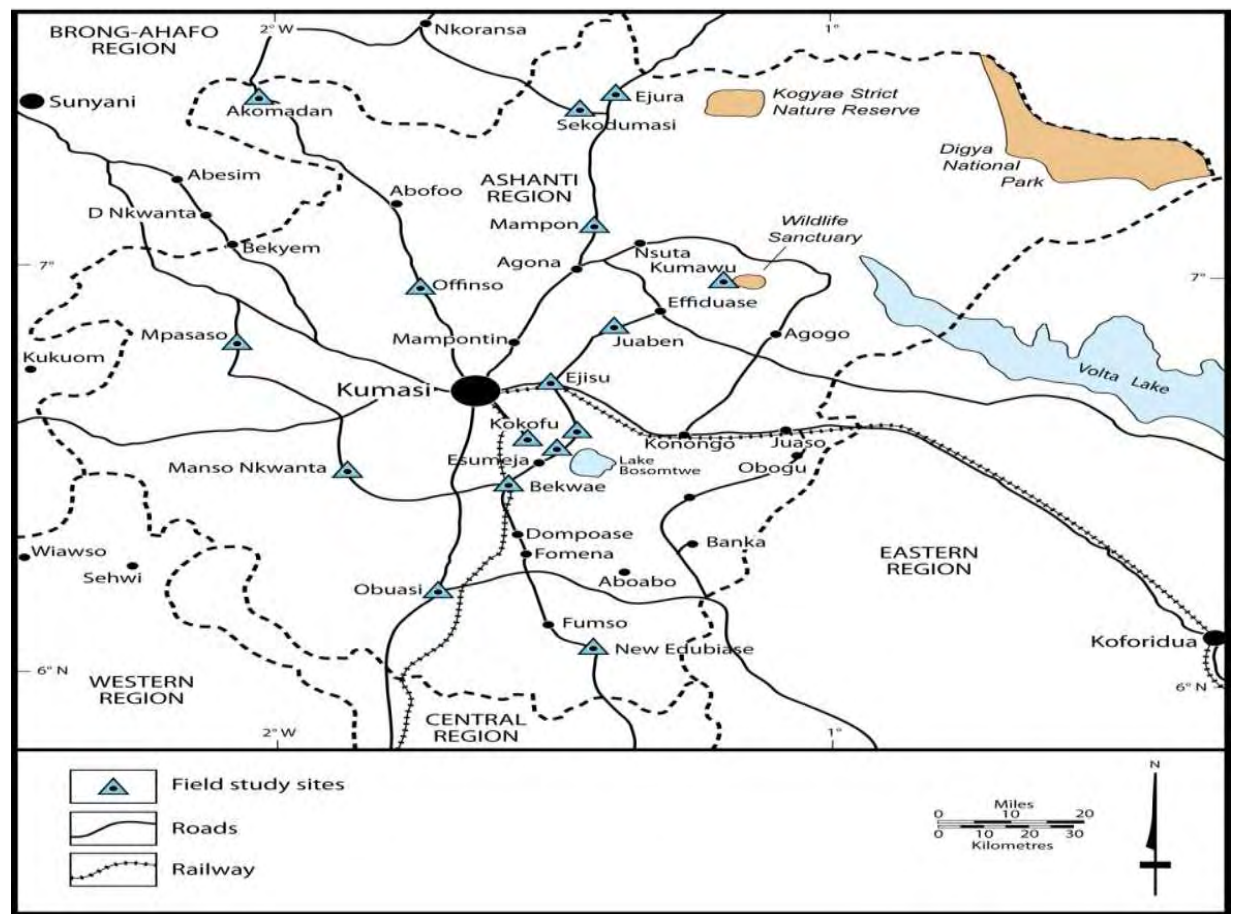

Fig. 1: Geographical Location of Sampled Settlements in Ashanti Region, Ghana.

Source: Author's Construct, 2008

tial and political configurations" (Rangan, 2000).

In this paper, the analytical approach of political ecology is used (Blaikie and Brookfield, 1987, Rangan, 2000; Robbins, 2004) to develop a framework for examining the processes that have shaped forest cover change in the Ashanti Region of Ghana (Agyeman, 2008). Blaikie and Brookfield (1987) describe political ecology as an interdisciplinary approach that combines "the concerns of ecology and a broadly defined political economy" for understanding the different ways in which land degradation and social marginalization are interlinked.

The approach involves examining how activities occurring at different geographic levels and hierarchies of socio-economic organization (e.g., person, household, village, region, state, and world) interact with environmental processes of change to produce varied ecological landscapes and social contradictions in regions.

There are two reasons why a political ecology approach can provide a more realistic understanding of how forest cover change has occurred in the Ashanti Region of Ghana. First, its focus on understanding environmental variability and spatial variation means that it allows landscape change, rather than forest loss in regions. Second, its focus on examining interactions between political, economic, and environmental processes across different spatial levels opens up new ways of reconstructing past landscapes by looking at historical patterns of settlement and regional trade and forms of institutional control over people, resources and forms of production. 
In order to understand the processes of forest cover change in the Ashanti Region of Ghana, the study is focused on the social and ecological transformations that have occurred over time through changes in:

- the forms of production, consumption, and accumulation based on extraction and manipulation of natural resources;

- the forms of institutional control- customary, legal, or extra-legal- over land, natural resources and people, which shape how human labour and technologies are organized and employed in various kinds of economic activities;

- linkages between different kinds of economic activities, and how these contract, expand or get replaced by others; and

- the differing conceptions of forest and natural resources held by administrators and local populations, and the conflicts that arise around institutional control of these resources.

The historical context extends from the late 1600 s to the present, and is divided into five phases. The first phase is from 1680 to 1807 , which marks the rise of the Asante nation-state, its political expansion and control over the regional economy, and engagement with the trans -Atlantic slave trade until it was officially abolished in 1807 by European government. The second phase is from 1807 to 1900 , which marks the changes in economic activities after the abolition of the slave trade, the reorganization of economic activity under Asante rule, and the expansion of British influence in the Gold Coast during the last decade of the $19^{\text {th }}$ century. The third phase, which is from 1900s to 1957 , examines the changes of economic activity and institutional regulation of land and natural resources under British colonial rule in the region until its formal end in 1957. The fourth and fifth phases, from 1957 to the present marks the post-colonial rule period, and examines the economic strategies, land and forest use policies pursued by the governments of Ghana. These two phases are distinguished by the events that occurred in the 1980s (19571983 and 1983-2000) - fiscal crisis and structural adjustment, droughts, and widespread forest fires. This had a strong influence on the livelihood activities, cultivation practices, and land tenure strategies pursued by households in the Ashanti Region of Ghana.

The analytical framework in Fig. 2 provides a clearer and more realistic understanding of how forest zones in West Africa have been transformed over time. It focuses on the ways in which nested rights and production cycles of forest continuum communicate to simultaneously generate two forms of land conversion (Diaw, 1998): first, the physical conversion of land cover and use, and second, the social conversion of land ownership and access regimes. The framework reveals how several layers of rights are intertwined into different segments of forested landscapes, and how different access regimes interact to reshape these landscapes over time. The most useful and important aspect of this analytical approach is the fact that it neither assumes nor contributes to the dominant assumptions underlying the discourse of deforestation in West Africa. It pays close attention to the ways in which forests in West Africa have undergone transformations over long periods of time through the cultivation practices of communities in the forest zone. As Diaw (1998) points out, "Agriculture has also been historically on long term productive cycles that imply several mutations and transmutations of the natural and social statuses of land. This cycling is neither linear nor unique, and leads to numerous variants. It has led to the reconstitution of secondary and mature primary forests after a period of agricultural uses in many areas (Diaw, 1998).

The Ashanti Region in the Forest Transformation Process (1600-2000)

The Ashanti Region is located in the middle belt of Ghana. It lies between longitudes $0.15^{\circ}$ $\mathrm{W}$ and $2.25^{\circ} \mathrm{W}$ and latitudes $5.50^{\circ} \mathrm{N}$ and $7.46^{\circ}$ $\mathrm{N}$ and covers 24,390 square kilometers, which is $10.2 \%$ of the land area of the country. Its 


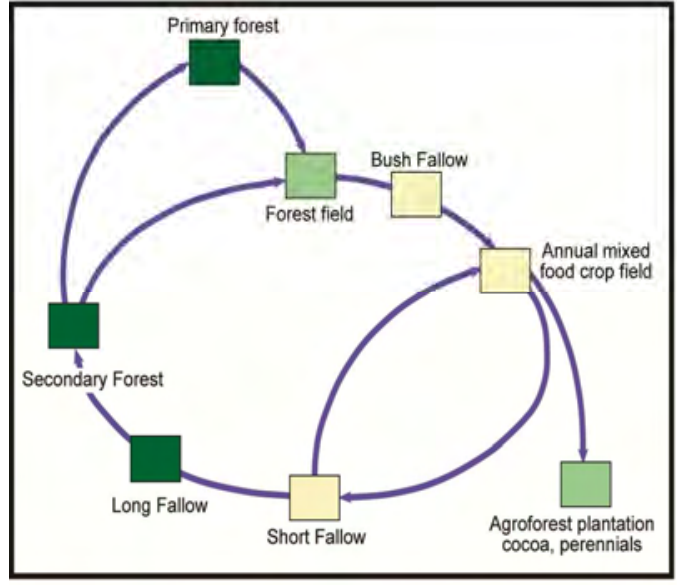

Production cycles and land conversion

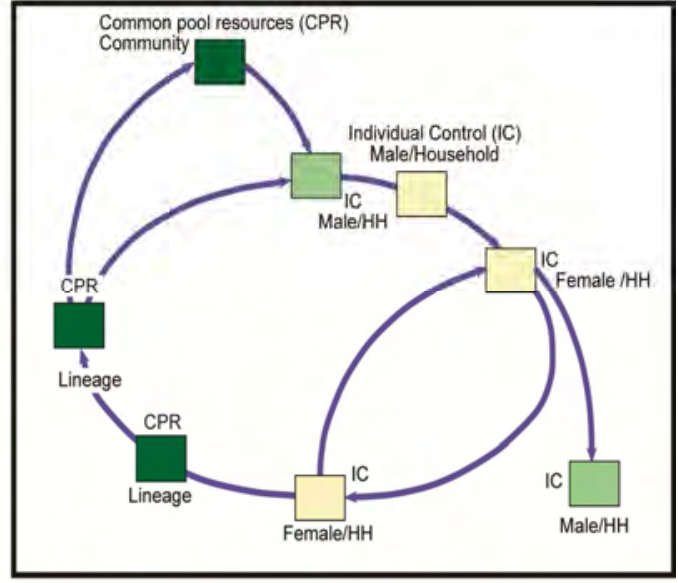

Social conversion of land status

Fig. 2: Forms and Cycles of Forest Zones Transformation in West Africa Source: Diaw 1998

population in 2000 was $3,612,950$, representing $19.1 \%$ of the national total.

In the 1600s, the settlements along the Coastal Plains were organized in small units made up of old inhabitants and Akan speaking peoples who had migrated down from the north through the forests of the Ashanti kingdom in the $12^{\text {th }}$ century or earlier (Agyeman, 2008).

Rattray (1929) suggests that Asante settlers may have engaged in a combination of hunting and forest farming and established settlement clusters or villages under family heads. These settlements became well established by the $15^{\text {th }}$ century and as population grew, some of the Asante clans moved out of the settlements (Rattray, 1929). As Wilks (1975) notes, the heavier the forest cover through which people travelled, the slower the journey. With reference to the great roads (Agyeman, 2008), all the four southern routes cut through the forest zone, and the number of halting villages along these routes indicate the relative slowness of travel in forested areas compared with the northern routes.

The typical Asante forest-farmer of the $17^{\text {th }}$ and $18^{\text {th }}$ centuries cultivated a mix of food crops such as plantains, cocoyams, cassava and maize
(Rattray 1923; Lewin, 1978). Kola and oil palm trees already existing on the land were safeguarded and their valuable products harvested for household use and trade. Fig. 3 provides an illustration of how production cycles and processes of land conversion during the $17^{\text {th }}$ and $18^{\text {th }}$ centuries are likely to have transformed forest cover in the Ashanti Region.

Forestry experts have generally assumed that population growth and deforestation in the Ashanti Region of Ghana occurred primarily in the 20th century. However, when we extend the frame of references to include the $17^{\text {th }}$ and $18^{\text {th }}$ centuries, we can see that there is a more complex process of demographic and forest cover change in the region. The rise and expansion of the Ashanti power brought about substantial changes in population concentration, settlement patterns, and land use in the territories that came under their control. Wilks (1975, 1993) estimates that metropolitan Ashanti with its capital Kumasi and the surrounding agglomeration of towns and settlements falling entirely within the forest zone covered an area of 25,000 sq. $\mathrm{km}(9,652.5$ sq. miles $)$.

Wilks (1975) estimated that by the beginning of the $19^{\text {th }}$ century, the population of metropolitan 


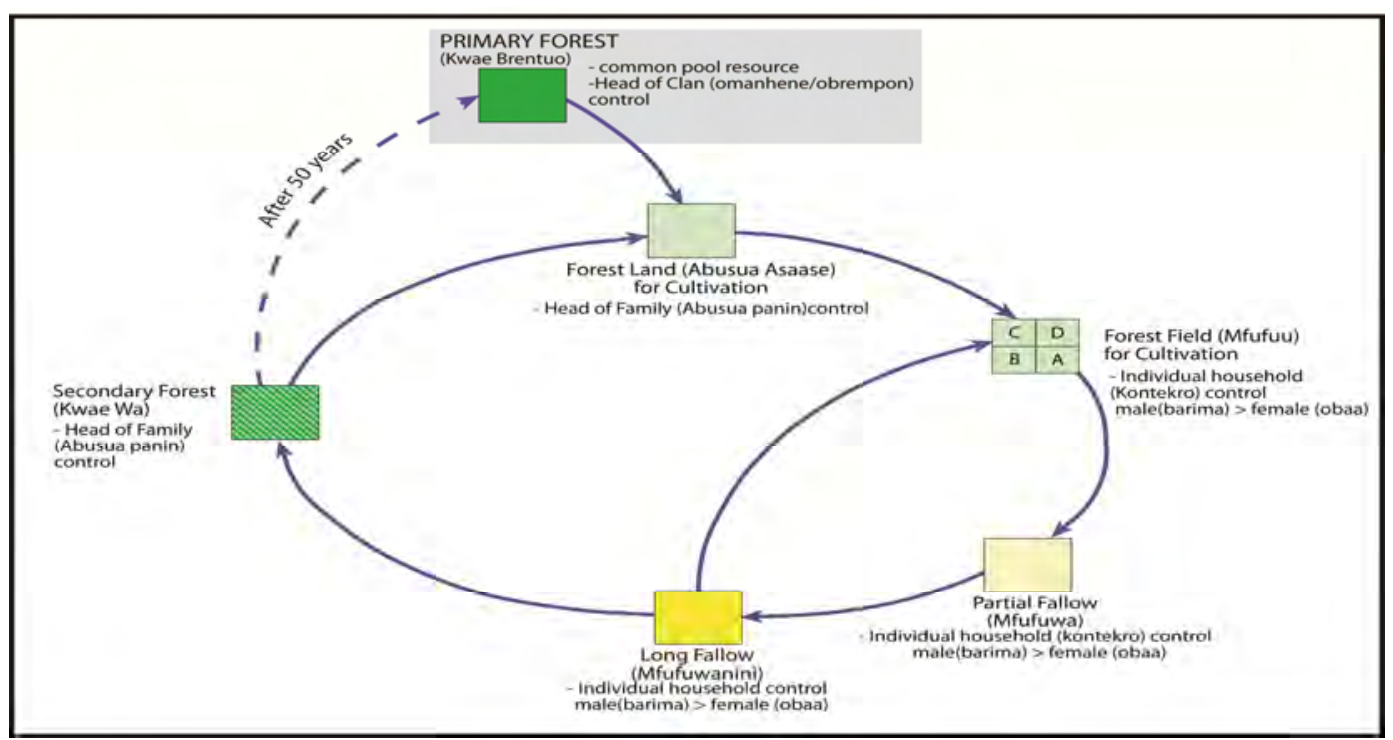

Fig. 3: Production Cycles and Forest Conversions in Asante, 1600s-1800

Source: Adapted from Diaw, 1998.

Ashanti may have ranged between 500,000 and 725,000 people. When combined with estimates of per capita land use in the shifting cultivation system, the extent of forested areas under cultivation and fallow within metropolitan Ashanti would have ranged between 600,000 and 870,000 hectares (Wilks, 1975). Fairhead and Leach (1998) comment that Wilks' (1975) estimates of population and land use may be conservative because village sites frequently moved as fresh areas were brought into cultivation. Even if we based our calculations on Wilks' (1975) estimates, it is likely that $25-40 \%$ of the forest cover in metropolitan Ashanti would have been altered during the $18^{\text {th }}$ century. The estimates of forest cover change would be greater if the routine clearing and maintenance of the eight Great Roads (Fig. 3.4, Agyeman, 2008) leading out of Kumasi and associated halting places were taken into account.

Fig. 4 attempts to reconstruct the patterns of land use and forest cover in the region at the end of the $18^{\text {th }}$ century. It is estimated that metropolitan Ashanti represented only one-tenth of the area controlled by the Ashanti Empire, and that the forested landscape had already been changed during the two previous centuries. The constant warring between the Asante clanstates and neighboring kingdoms during the $16^{\text {th }}$ century and the emergence of the Atlantic slave trade could have resulted in population decline and the expansion of forest cover in these territories. The subsequent union of Asante clan-states at the end of the $17^{\text {th }}$ century could have altered the patterns of population concentration and forest cover in the region. Since most of the slaves were obtained from vassal states to the north, the southwest and southeast of metropolitan Ashanti now Ashanti Region, the increase in the Atlantic slave trade could have resulted in further population decline and expansion of vegetation cover in the rainforest. It is likely that at the end of the $18^{\text {th }}$ century the greatest amount of population growth and forest conversion could have occurred in the moist semi-deciduous forest zone occupied by metropolitan Ashanti. Contrary to the commonly held assumptions of contemporary forestry experts, the forested zones of Ashanti were far from being primeval or uninhabited areas prior to the $19^{\text {th }}$ century. 


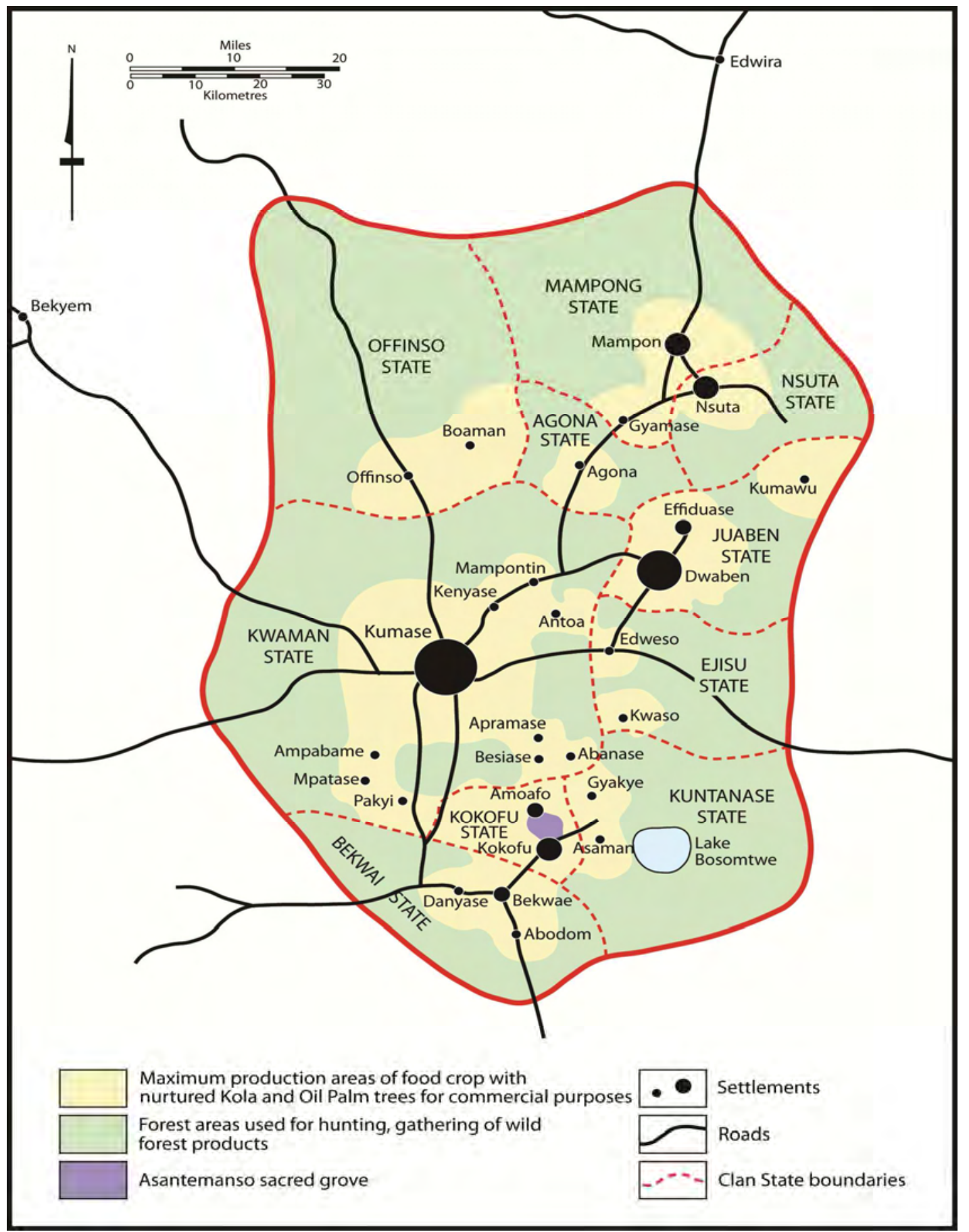

Fig. 4: Forest Cover and Landuse in Metropolitan Ashanti, 1600- 1800s. Source: Based on Wilks, 1975 and Austin, 1987. 


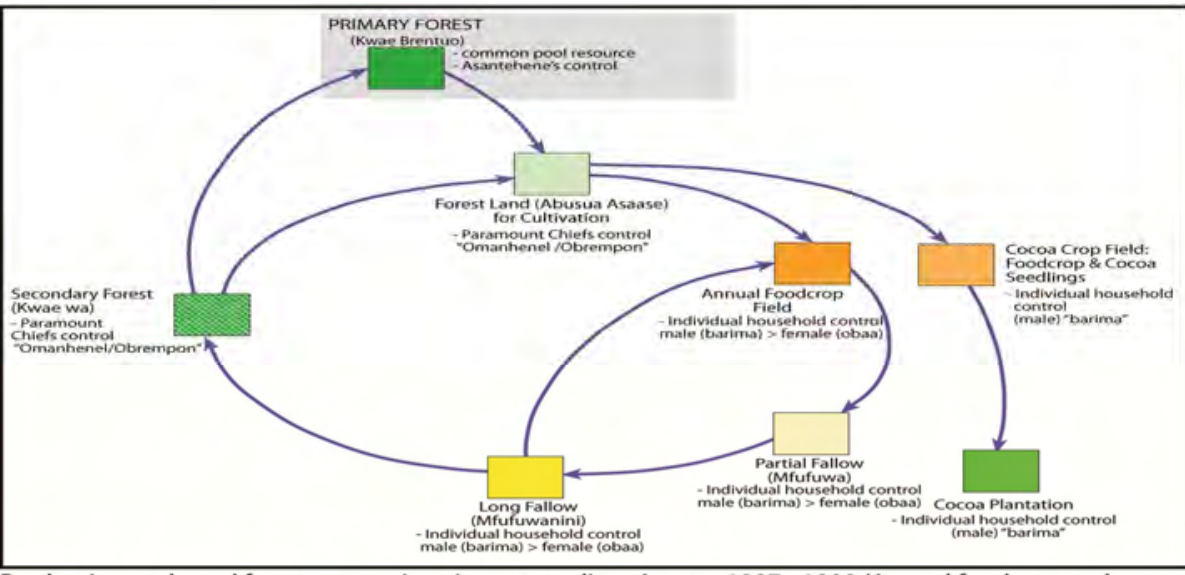

Production cycle and forest conversions in metropolitan Asante, 1807 - 1900 (Annual foodcrop and cocoa production)

b

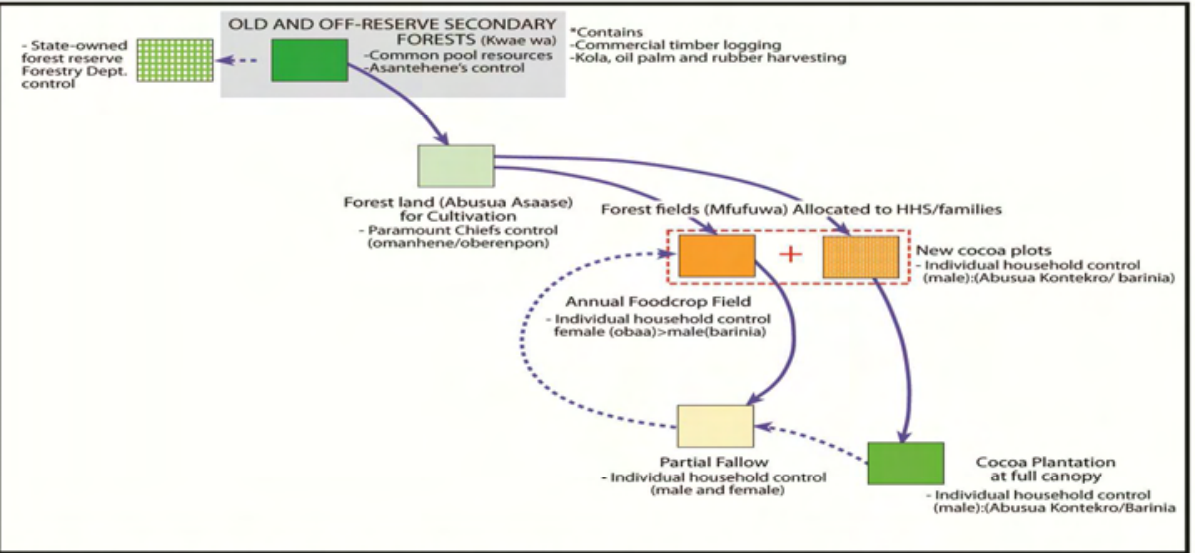

Production cycle and forest conversion in Ashanti, 1900 - 1957 (Annual foodcrop and cocoa production

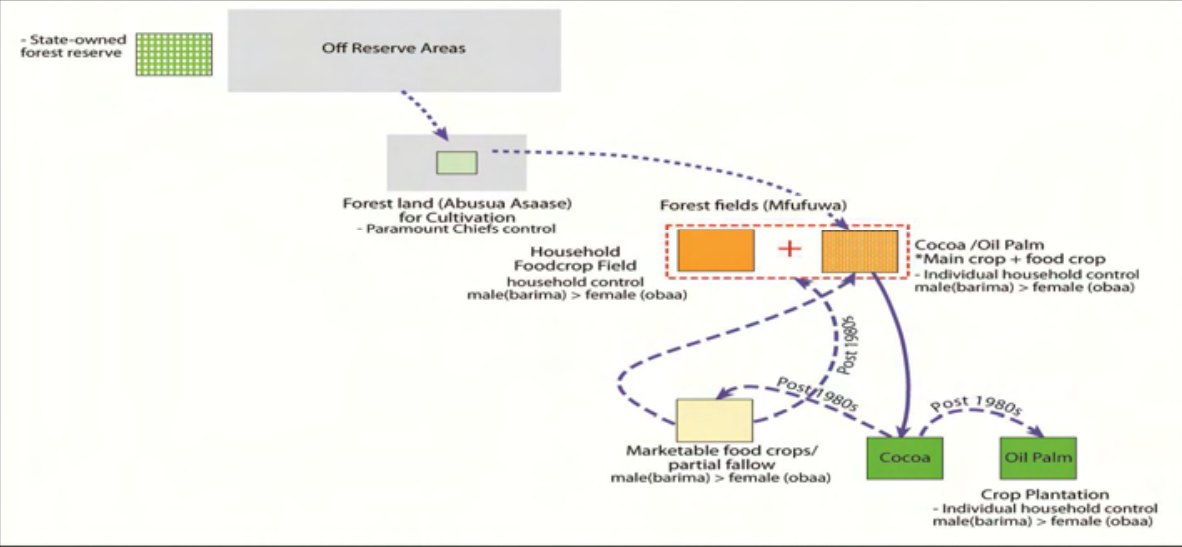

Production cycle and forest conversions in Asante Region, 1957 - 2000

Fig. 5: Comparison of Production Cycles and Forest Conservations in the Ashanti Region, 1807-2000

Source: Author's Construct, 2008

Journal of Science and Technology @ KNUST April 2012 
The growth in commodity exports during the second half of the $19^{\text {th }}$ century $(1809-1900)$ had a significant effect on agricultural patterns in the Gold Coast (Ghana). Palm oil and palm kernel production that previously was limited to harvests from naturally occurring trees in fields and forest areas expanded through small- scale plantations. Food crop cultivation for subsistence and local demand largely followed the same patterns as the previous century, using forest fields that had been under short or long fallows.

The most significant shift in agricultural production patterns occurred with the introduction of cocoa cultivation in the last quarter of the $19^{\text {th }}$ century. Due to the semi- permanent nature of the crop, areas under cocoa cultivation were maintained as such and not subjected to the seasonal and shifting food crop production . This meant that there was less land that reverted from the status of fallow to secondary forest. Farming households involved in cocoa cultivation modified their systems of land holding and food production, and their fields for longer periods of time (see Fig. 5a).

Ashanti's economy was completely integrated with the Gold Coast now Ghana by the end of the 19th century. Fig. 6 shows how this integration may have shaped the patterns of land use and forest cover within the territories of Metropolitan Ashanti. Most of the areas surrounding Kumasi and to the north continued the traditional systems of resource extraction and food crop cultivation. Kola nut extraction was scattered across the territory. Cocoa cultivation entered the Amansie region of Metropolitan Ashanti in the late 1890s, and was mainly concentrated in Bekwai, Kokofu and Kuntenase.

The Amansie region of Ashanti also experienced significant changes in forest cover due to the intensification of tropical hardwood logging and gold mining in the last decades of the 19th century.

The forest cover and biogeographical landscape of Ashanti was to undergo further transformation in the coming decades. The expansion of cocoa cultivation and the colonial government's attempts to transform land tenure systems and natural resource extraction were key factors that influenced the changes to land use and forest cover in the Ashanti Region.

Sir Gordon Guggisberg observed that round-log timber was "the next best product if not a better one than cocoa" (Kay, 1972). In 1906/07, the Gold Coast government passed the Timber Protection Ordinance, which banned the felling of commercial timber species below a specified diameter, and proposed a more organized system for controlling and managing the exploitation of forest resources. H.N. Thompson, the very first trained forester employed by the $\mathrm{Ni}$ gerian Forest Department who had earlier worked in British Burma, was employed by the Gold Coast government in 1908 to carry out an assessment of the colony's forested areas (Sayer et al., 1992).

Following Thompson's assessment, the colonial government established a Forestry Department which was to take responsibility of managing all forest estates created by the government and ensure a sustained supply of forest resources mainly timber and protect the government's estates. The Forestry Department requested the Governor to reserve forest areas that needed to be protected from destruction in the public interest (Foggie 1962; FRMP Project files, 1989). Five years later, the colonial government put forward the Forest Bill of 1911. The 1927 Forest Bill highlighted these issues in setting out the need for creating forest reserves. The rationale for reservation was to protect major hills and watersheds to ensure water supply for agriculture and fuel wood needs.

In Ashanti Region, more than 20 forest reserves were created; the Asantemanso sacred grove was incorporated into a forest, and a protected area was created around the Bosomtwe Lake (Hall and Swaine, 1981; Forestry Department, 1994). The most striking development in 


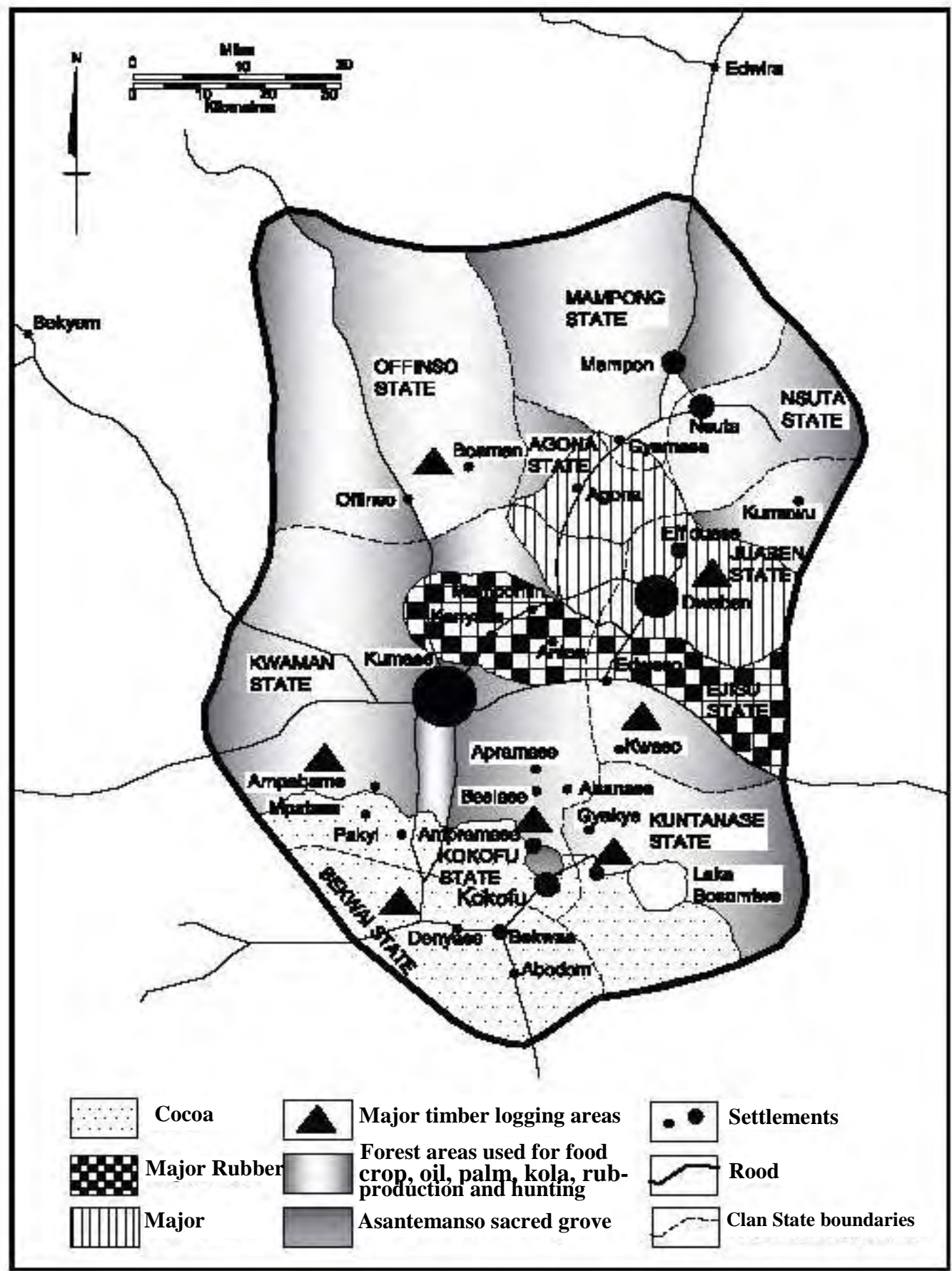

Fig. 6: Land and Forest Cover in Metropolitan Ashanti Region, 1807- 1900. Source: Based on: Wilks, 1975, 1993; Kimble, 1963; Hill, 1963;Ward, 1967; Schwimmer, 1980 

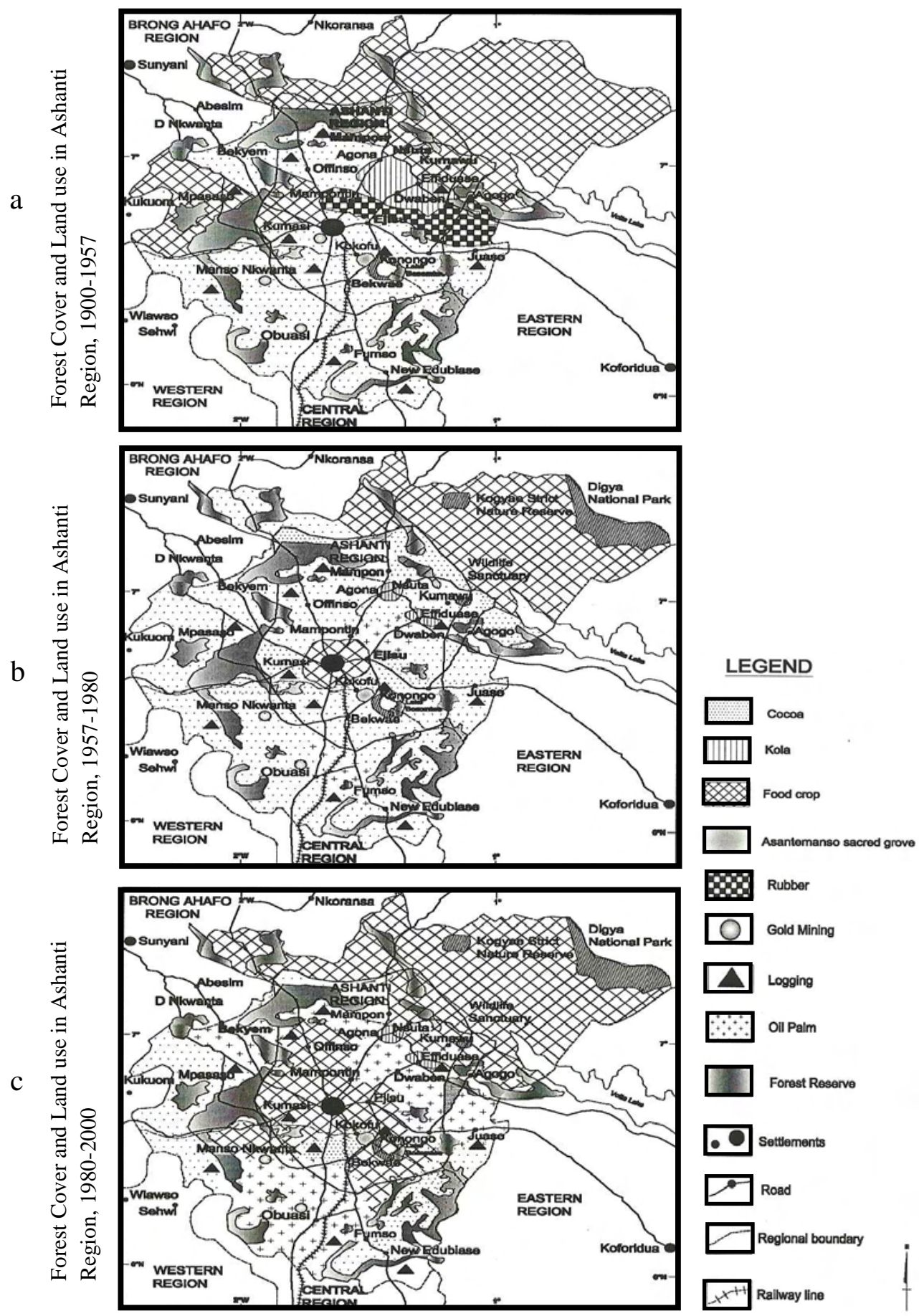

Fig. 7: Comparison of Land use Change, Cycles of Production and Forest Conversion Source: Agyeman, 2008 
Ashanti between 1900 and 1957 was the expansion of cocoa cultivation, which led to forest farming areas becoming dominated by the crop.

Fig. 5b shows the changes in household production cycles and forest conversions during the period. Fig. 7a shows the land use and forest transformations that emerged in the Ashanti region at the end of colonial rule in 1957. By the mid-1950s, cocoa was the dominant forest farming crop in the region. Fig. $7 \mathrm{~b}$ shows the nature of changes in land use that have occurred in the Ashanti Region. Food crop cultivation replaced cocoa around Kumasi and extended outwards to the north beyond Offinso and to the Southern towns such as MansoNkwanta and Kokofu. In the aftermath of the drought and bushfires in 1982/83, cocoa farmers in Ashanti faced the question of whether to recultivate and rehabilitate their cocoa farms or to convert the damaged areas to other agricultural crops. Given the difficult conditions under the Structural Adjustment Programme and rising inflation, some farmers converted part of their cocoa plots to cultivate food crops. Others moved out of cocoa cultivation and entered into oil palm cultivation. Cocoa production, which had been fairly extensive across the Ashanti Region between 1957 and 1983 was now concentrated in the districts near New Edubiase, Bekwai and Mpasaso.

The land tenure and production cycles have also undergone substantial changes in the postbushfire period (after the 1983 bush fires). The most important feature is the significant reduction (close to absence) of 'off reserve', secondary forests (kwae wa) that traditionally would have been under the Asantehene's control. The forest land for cultivation (abusua asaase), which would have been allocated to households by paramount chiefs or heads of clan, became extremely limited partly because most households converted their ageing or damaged cocoa farms to food crop or oil palm production rather than leaving these areas under long fallows, (see Fig. 5c). As Fig. 7c shows, after the 1980s, most households kept some of their forest fields under longer term tree crops such as cocoa and oil palm, and converted other farm plots to intensive food crop cultivation with very short, partial fallow periods.

\section{Respondents' Views Regarding Future Cover Changes in the Ashanti Region}

Almost all respondents felt that the forest cover and secondary vegetation associated with mature cocoa family are likely to decline in the northern parts of Ashanti, especially in the Offinso and Mampong sub-regions. These are areas where maize, cassava, yam cultivation have been well established over the past few decades, and also where vegetable crop production for export has substantially expanded into cocoa areas. Most farmers in these northern sub -regions have come to accept the land use changes from cocoa to maize, cassava, yam, and tomatoes as being most suitable in terms of livelihood, profitability and prevailing ecological conditions that are more transitional woodland-savanna in character. Many farmers have found the savanna woodlands and grassland landscape in the Mampong area more conducive to large-scale cultivation of maize using mechanization, something that could not be done before when cocoa and other tree crops such as rubber and kola dominated the landscape (Table 7.8, Agyeman, 2008 : 217).

Respondents from Juaben and Obuasi observed that the non-availability of off-reserve forest areas combined with the conversion of cocoa areas to oil palm meant that there would be less secondary forest cover in their sub-regions.

They noted that areas under oil palm in these sub-regions were likely to remain so because these areas cannot be easily converted to production of cocoa and food crops such as plantain or cocoyam. However, the respondents from Bekwai and Manso Nkwanta noted that if the economic profitability of cocoa improved and was supported by government policies that encouraged restoration of mixed tropical tree crops and secondary forest cover, then forest cover was likely to increase in the southern and 
central sub-regions of Ashanti.

\section{Rethinking Tropical Forest Cover Change} The central argument of this paper is that the dominant global discourse of tropical deforestation obscures the more complex processes that contribute to changes in forest cover and landscapes in tropical regions of the world. The term deforestation signals a unidirectional change from a presumed undisturbed state of dense forest to a state of irreversible forest loss, causing destruction of fragile ecosystems, extinction of species, soil erosion, water shortages and global climate change. It rarely acknowledges the ways in which forests may have been used, exploited, and shaped by local communities in the past, and how the forest cover may have undergone qualitative changes rather than being completely destroyed by human activity.

According to Agyeman (2008) the land use change and forest transformations in Ashanti Region indicate that neither of these types of narratives is effective in understanding the processes of forest cover change in the Ashanti Region. Historical analysis reveals that the forested landscape of Ashanti has been constantly used and reshaped over the past five centuries by settlement, economic activity, regional trade, and political reorganization of the territory in the pre-colonial times by Akan states, kingdom and the Asante Empire.

The pre- colonial changes to the forested landscape were not minimal or primitive in character, but substantially linked to the broader economic processes that linked the Ashanti Region and West Africa more generally to the movement of slaves, gold and trade.

Colonial rule followed on, and led to different patterns and intensities of resource exploitation that gave rise to a qualitatively different forest landscape. The five decades that followed the end of British colonial rule produced different patterns of land use and forest transformation within Ashanti Region and the other forested zones of Ghana.
The main issue for tropical forest management in Ghana concerns the kinds of intra- and interland use and forest management activities involving farmers, researchers, and field agencies might revitalize tropical forest. The key actors in this process must be the farmers who are confronted with a wide range of ecological, economic, and institutional factors that affect their agricultural activities. Thus improvement of forest cover in Ashanti would basically depend on the effective functioning of forest farming techniques and agricultural technologies that would allow for mixed food and treecropping systems. Forest farming is the most sustainable and reliable land use system that has the potential to sustain tropical forest cover and improve the ecological conditions for subsistence and commercial crop production in the moist semi-deciduous forest zones of West Africa. The cultivation of leguminous multipurpose trees alongside oil palm and commercial food crops, alley crop farming and livestock farming, could offer positive ecological, economic and social benefits to farmers.

In order for sustainable forest farming and tropical forest management to succeed, it is necessary to focus on the needs, knowledge and participation of farmers and other natural resource users. As this study shows, local farmers are keenly aware of how economic, ecological, and political factors combine to shape their farming environments and forest cover in the region. Hence any attempt to engage in forest cover conservation, expansion or management need to start from local farmers and other forest resource users' perceptions and understandings of the patterns and reasons shaping land use, production cycles and tenure systems. Even though international experts and agencies can bring scientific knowledge, capital and high technology to address the 'deforestation problem', they cannot achieve much without learning from local farmers and resource users and gaining their support. Forest cover management is likely to be more effective and adopted more readily if the design of environmental measures 
Forest transformation in Ashanti Region...

reflect a dynamic understanding of local variations of forest farming practices, production cycles and tenure patterns and how they can or might change under different circumstances. Such an approach, which moves beyond the typical linear deforestation discourse and its Malthusian condemnation or populist romanticism, is likely to be more successful in promoting alternative types of ecologically sustainable forest farming and land use systems in the tropical forest zones of Ghana and West Africa.

\section{CONCLUSION}

The study shows that the dynamics of tropical forests in West Africa need to be understood as part of a human biogeographical process that is not always unidirectional, that is, from luxuriant dense tropical forests to inferior land use systems practiced by ignorant farmers. There is no doubt that the forest cover in Ashanti Region has changed over the past century from being more uniformly dense to a landscape that has much greater variation in density of forest cover. But as they point out, much of the analytical basis of the deforestation literature is flawed because it does not adequately take into account the interactions between economic, ecological, and political processes that have shaped land use and forest cover in this region for the past 400 years and more. As this study shows, these processes come together in different production cycles and patterns of forest conversion. Rather than thinking of forest cover change as a linear process of loss, it is more relevant to see how different production cycles and systems of tenure in forest farming create patterns of forest cover that spread or become denser during some phases and reduce in an area or become more scattered at other times.

\section{REFERENCES}

Agyeman, K. O. (2008). Land Use Change and Forest Transformations in the Ashanti Region, Ghana. PhD. Thesis, Monash University, Melbourne, Australia, 251pp.

Amanor, K. S. (1994). The New Frontier: Farmer responses to land degradation.
London: UNRISD and Zed Books.

Amanor, K. S. (2002). Bushfire management, culture and ecological modernisation in Ghana. Institute for Development Studies, 33 (1): 65-74.

Austin, G. (1987). The emergence of capitalist relations in South Asante cocoa farming, 1916-33. Journal of African History, 28: 259-279.

Batterbury, S. and Bebbington, A. (1999). Environmental histories, access to resources and landscape change: an introduction. Land Degradation and Development, 10 (4): 279-288.

Benhin, J. and Barbier, E. (2004). Structural Adjustment Programme, deforestation and biodiversity loss in Ghana. Environmental and Resource Economics, 27 (3): 337-366.

Benneh, G. (1985). Socio-economic responses to climatic changes. EPC Workshop on Combating the Effects of Drought and Desertification, pp. 49-57. January 24-25.

Blaikie, P. and Brookfield, H. (1987). Land degradation and society. London: Methuen.

Brown, K. and Pearce, D. (1994). The causes of tropical deforestation: The economic and statistical analysis of factors giving rise to the loss of tropical forests. London: UCL Press.

Diaw, M. C. (1998). From sea to forest: an epistemology of otherness and institutional resilience in non-conventional economic systems. Paper presented at the International Association for the Study of Common Property (IASCP) Conference. Vancouver BC, Canada, July.

Dickson, K. B. (1983). The urban-rural contrast in Ghana and its implications for rural development. J.B. Danquah Memorial Lectures, Accra: Ghana Academy of Arts and Sciences. 
Fairhead, J. and Leach, M. (1996). Misreading the African landscape: Society and ecology in a forest-savanna mosaic. Cambridge: Cambridge University Press.

Fairhead, J. and Leach, M. (1998). Reframing deforestation: Global analyses and local realities - Studies in West Africa. London: Routledge.

FAO. (1993). Forest Resources Assessment, 1990, Tropical Countries. Forestry Paper 112. Rome: FAO.

FAO. (1997). State of the world's forests 1997. Rome: FAO.

Foggie, A. (1962). The role of forestry in the agricultural economy. In J.B.Wills (ed). Agriculture and Landuse in Ghana, pp. 229-235. Oxford: Oxford University Press.

Forestry Department. (1994). Interim measures to control illegal timber harvesting outside forest reserves. Kumasi: Forestry Department, Planning Branch.

Forsyth, T. (2003). Critical Political Ecology: The politics of environmental science. London: Routledge.

FRMP. (1989). The Forest Resources Management Programme. Project Files. Kumasi: Forestry Department, Planning Branch.

Gyasi, E., Agyepong, G. T., ArdayfioSchandorf, E., Enu-Kwesi, L., NabiJa, J. S. and Owusu-Bennoah, E. (1995). Production pressure and environmental change in the forest-savanna zone of Southern Ghana. Global Environmental Change, 5 (4): 355-366.

Hall, J. B. and Swaine, M. D. (1981). Distribution and ecology of vascular plants in a tropical rain forest: Forest vegetation in Ghana. The Hague and Boston: W. Junk and Kluwer.

Hawthorn, W. and Musah, A. (1995). Forest protection in Ghana with particular Reference to Vegetation and Plant Species.
Gland, Switzerland and Cambridge: IUCN in collaboration with ODA and the Ghana Forestry Department.

Hill, P. (1963). The migrant cocoa-farmers of Southern Ghana: A study in rural capitalism. Cambridge: Cambridge University Press.

Kay, G. B. (1972). The political economy of colonialism in Ghana: A collection of documents and statistics, 1900-1960. London: Gregg Revivals.

Kimble, D. (1963). A political history of Ghana: The rise of Gold Coast nationalism. Oxford: Clarendon Press.

Kuofor, K. (2004). New Institutional Economics and the failure of sustainable forestry in Ghana. Natural Resources Journal, 44(3): 743-760.

Leach, M. and Fairhead, J. (2000). Challenging neo-Malthusian deforestation analyses in West Africa's dynamic forest landscapes. Population and Development Review, 26 (1): 17-43.

Lewin, T. J. (1978). Asante before the British: The Prempean Years, 1875--1900. Lawrence, KS: University of Kansas Regents Press.

Myers, N. (1991). Tropical Forests: Present status and future outlook. Climatic Change. 19: 3-22.

Myers, N. (1994). Tropical deforestation: Rates and patterns. In K. Brown and D. Pearce (eds.) The Causes of Tropical Deforestation. London: UCL Press.

Nsiah-Gyabaah, K. (1996). Environmental degradation and desertification in Ghana. Avebury, UK: Ashgate.

Rangan, H. (2000). Of myths and movements: Rewriting Chipko into Himalayan history. London: Verso.

Rattray, R. S. (1923). Asante. Oxford: Claren- 
Forest transformation in Ashanti Region...

don Press.

Rattray, R. S. (1929). Asante Law and Constitution. Oxford: Clarendon Press.

Robbins, P. ( 2004). Political Ecology. Oxford: Blackwell.

Sayer, J., Harcourt, C. S. and Collins, N. M. (1992). Conservation Atlas of Tropical Forests: Africa. Cambridge: World Conservation Monitoring Centre and IUCN.

Schwimmer, B. (1980). The organisation of migrant farmer communities in Southern Ghana. Canadian Journal of African Studies, 14 (2). 221-238.

Ward, W. E. F. (1967). A history of Ghana.
London: George Allen and Unwin.

Watts, M. (2003). Development and Governmentality. Singapore Journal of Tropical Geography, 24 (1): 6-34.

Wilks, I. (1975). Asante in the Nineteenth century: The structure and evolution of a political order. Cambridge: Cambridge University Press.

Wilks, I. (ed). (1993). Forests of Gold: Essays on the Akan and the kingdom of Asante. Athens, OH: Ohio University Press.

World Resources Institute (WRI). (1990). World Resources 1990-1991. Oxford: Oxford University Press. 